HERKE-FÁBOs Barbara Katalin

DOI: 10.15170/DIKE.2018.02.02.03

tanársegéd

PTE ÁJK

\title{
A gyermekvédelmi rendszer prevenciós szerepe a bünmegelőzésben a Csemegi-kódextől napjainkig
}

\begin{abstract}
Preventive Role of the Child Protection in Crime Prevention from the Code Csemegi until Today

The delinquency of children of tender age and juveniles is a social phenomenon of specific concern. This is the group of offenders concerning which jurisprudence, jurisdiction, social services and any other organizations coming into contact with juvenile offenders are able to do the most in order to have the youth become law-abiding citizens as adults. The authority measures that are performed in the frame of the administrative procedure provide a part in the Hungarian child protection system. The authority measures of the Hungarian child protection care system can be grouped according to its reason and system of instrument as a kind of protecting-safeguarding action furthermore as measures that result in the removal of the child from his family. Preventive patronage has been of legal force since the $1^{\text {st }}$ of January 201. In Hungarian areas of law this new legal institution has roots in criminal law and it got placed into the system of child protection based on the authorization of the 1430/2011 (XII. 13.) governmental decision despite the fact that the reasons of its creation were first and foremost the reduction of child-and juvenal criminality and the effective reintegration of the perpetrators.
\end{abstract}

Keywords: child protection system, authority measures, crime prevention, risk assessment

\section{A családjog és a büntetőjog kapcsolódási pontjairól}

A gyermekvédelem feladat- és eszköztára tekintetében számos jogterülethez kapcsolódik, ezért a célkitűzések megfogalmazásához és a következtetések levonásához a jogterületek komplex vizsgálata és értelmezése szükséges.

A bűnmegelőzés preventív eszköztárába tartozó megelőző pártfogás jogintézménye a jogágak metszéspontjában áll. A jogpolitikai cél a kriminológia és a büntetés végrehajtás területét érinti. A büntetőjogi kapcsolat a büntethetőség objektív és szubjektív kategóriájából vezethető le. Az életkor és a belátás vizsgálata jelöli ki a gyermek- illetve fiatalkorúval szemben alkalmazható felelősségrevonási eljárás színterét. Amennyiben a hivatkozott feltételek hiányoznak, úgy a gyermekvédelem rendszere közigazgatási hatósági eljárás keretében lép fel a gyermek érdekében. Ebben az esetben csak tényállásszerűség valósul meg, a büntetőjogi felelősségre vonás alapja hiányzik. Azonban annak teljessége esetén a fiatalkorú a büntető igazságszolgáltatás rendszerébe kerül. A gyermekvédelmi hatósági intézkedések két típusát különböztethetjük meg. A védő-óvó típusú intézkedések képezik az első csoportot, ide tartozik a megelőző pártfogás intézménye is. A 
második kategória a gyermek családjából történő kiemelésével járó beavatkozások. A különbségtétel alapja a szülői felügyeleti jog - alaptörvényi felhatalmazásból eredő - sérelme a gyermek- illetve fiatalkorú érdekében. A megelőző pártfogás elrendelése esetén nem kerül sor a gyermek családból való kiemelésére. Ugyanakkor a védelembe vétel mint ugyancsak védő-óvó típusú hatósági intézkedés minden egyes esetben kapcsolódik a megelőző pártfogás elrendeléséhez. A védelembe vétel felülvizsgálata már eredményezheti a gyermek családjából történő kiemelését.

\section{Az életkor}

\subsection{Az életkor bűnmegelőzési szempontú megközelítése}

Az életkor kérdése kitüntetett fontosságú a büntető felelősségre vonás és az alkalmazható jogkövetkezmények szempontjából. Az életkorhoz rendelt felelősség megállapításakor tekintettel kell lenni a gyermek személyiségét alakító tényezőkre és szocializációs hátterére. Bűnmegelőzési szempontból az életkorral kapcsolatban három releváns kérdés merül fel: 1, Mikor kerül kapcsolatba a gyermek vagy fiatalkorú személy a büntető igazságszolgáltatás rendszerével? 2, A gyermekvédelem vagy a büntető igazságszolgáltatás hatáskörébe tartozik-e felelősségének megállapítása? 3, Milyen közigazgatási hatósági intézkedés vagy büntető anyagi- illetve eljárásjogi intézkedés elrendelésére kerül sor, és az eléri-e célját? A három kérdésre adott együttes válasz alakítja egy-egy ország - nemzetközi jogharmonizációs kötelezettségeknek megfelelő - gyermekés fiatalkorúakra vonatkozó bűnmegelőzési politikáját.

A vétőképesség függvénye, hogy a felelősség megállapítása és a jogkövetkezmény meghatározása a gyermekvédelem vagy a büntető igazságszolgáltatás hatáskörébe tartozik-e. A gyermekvédelmi rendszer prevenciós hálózata elsősorban a veszélyeztetett gyermekre összpontosít. A büntető igazságszolgáltatás rendszerében kevésbé van lehetőség az egyéniesítő szempontok figyelembe vételére.

A tanulmány kiemelten foglalkozik a gyermekvédelmi hatósági intézkedések körébe tartozó, 2015. január 1. napjától hatályos megelőző pártfogás intézményével. Az intézkedés bevezetésére a gyermek- és fiatalkorú bủnelkövetők bűnözésének visszaszorítása, további bűnelkövetéstől való visszatartása érdekében került sor. A jogalkotó - a gyermekvédelmi jelzőrendszer tagjainak véleményét becsatornázva - felismerve azt, hogy a gyermekvédelmi rendszer keretében foglalkoztatott szakemberek nem rendelkeztek a bűnözéssel kapcsolatba kerülő gyermek- és fiatalkorúak kezeléséhez szükséges ismeretekkel. Ezért a jelzett problémára adott megoldásként a pártfogó felügyelők - büntető igazságszolgáltatás keretében szerzett - tapasztalataival kívánta a gyermekvédelem eszköztárát bővíteni. Az intézkedés bemutatása során életkori és fogalmi anomáliák tisztázására hívom fel a figyelmet, továbbá a gyermekvédelem bűnmegelőzési lehetőségeit szemléltetem.

A gyermek- és fiatalkorúak bűnmegelőzésével foglalkozó kriminológiai tanulmányok többsége szerint a hivatkozott személyek büntető igazságszolgáltatással történő minél fiatalabb korban való kapcsolatba kerülése „stigmaként” hathat a jövőbeni viselkedésükre. A gyermekek védelméről és a gyámügyi igazgatásról szóló 1997. évi XXXI. törvény (továbbiakban Gyvt.) 68/D. \(1) bekezdése szerint a gyámhatóság a bűncselekmény vagy az elzárással is sújtható szabálysértés 
elkövetése miatt indult védelembe vétel iránti eljárásban, vagy a már fennálló védelembe vétel mellett a nyomozó hatóságnak a bűncselekmény vagy a szabálysértési hatóságnak a szabálysértés elkövetéséről tájékoztató, a gyámhatóság felé tett jelzését követően megkeresi a pártfogó felügyelői szolgálatot környezettanulmány és a gyermek veszélyezettségének bűnmegelőzési szempontú kockázatértékelése beszerzése céljából.

A törvényi megfogalmazás ellentmondáson alapszik. Hatályos büntetőjogunk alapján ugyanis a gyermekkorú személy nem büntethető. A bűncselekmény törvényben meghatározott fogalmi elemei a büntetendőség, társadalomra veszélyesség és bűnösség. A Büntető Törvénykönyvről szóló 2012. évi C. törvény (továbbiakban Btk.) 15. \a) pontja alapján az elkövető büntethetőségét, illetve a cselekmény büntetendőségét kizárja vagy korlátozza a gyermekkor. Törvényi vélelem alapján a gyermekkorú személyek nem rendelkeznek beszámítási képességgel, így nem lehetnek alanyai sem bűncselekménynek, sem szabálysértésnek. A Btk. 16. \szerint nem büntethetô, aki a büntetendő cselekmény elkövetésekor a tizennegyedik életévét nem töltötte be, kivéve az emberölés, ${ }^{1}$ az erôs felindulásban elkövetett emberölés, ${ }^{2}$ a testi sértés, ${ }^{3}$ a terrorcselekmény ${ }^{4}$ a rablás ${ }^{5}$ és a kifosztás ${ }^{6}$ elkövetőjét, ha a bűncselekmény elkövetésekor rendelkezett a bűncselekmény következményeinek felismeréséhez szükséges belátással, mert ekkor tizenkét éves kortól büntethető. Márpedig a Gyvt. a megelőző pártfogás kapcsán beszél bűncselekményrôl és szabálysértésről, a meghatározás utolsó fordulatában pedig életkor szempontjából a gyermeket (és nem a gyermekkorút) említi.

A Gyvt. értelmező rendelkezései között a következő fogalom meghatározások találhatóak. Gyermek a Polgári Törvénykönyvről szóló 2013. évi V. törvény (a továbbiakban: Ptk.) 2:10. \(1) bekezdése szerinti kiskorú. Kiskorú az, aki tizennyolcadik életévét nem töltötte be. A kiskorú a házasságkötéssel nagykorúvá válik. ${ }^{7}$ Fiatalkorú az, aki szabálysértés elkövetésekor 14. életévét, 2013. július 1-jét megelőzően elkövetett bűncselekmény elkövetésekor a 14. életévét, 2013. július 1-jét követően elkövetett bűncselekmény elkövetésekor a 12. életévét betöltötte, azonban a 18. javítóintézetben történő nevelése esetében a 21. - életévét még nem töltötte be. ${ }^{8}$ Végezetül fiatal felnőtt az a nagykorú személy, aki a 24. életévét nem töltötte be. ${ }^{9}$

A Btk. értelmezésében fiatalkorú és felnőtt elkövetőkről beszélhetünk. A Btk. 105. \(1) bekezdése szerint fiatalkorú az, aki a bűncselekmény elkövetésekor a tizenkettedik életévét betöltötte, de a tizennyolcadikat nem. Tehát a Gyvt. és a hatályos Btk. a bűncselekmény elkövetése szempontjából ugyanazon életkorú csoportot tekinti fiatalkorúnak, ugyanakkor a gyermekkorú elkövetők életkorának rögzítése különbözik a két jogág meghatározásában. Míg a Gyvt. szóhasználatában ${ }^{10}$ gyermek szerepel, addig a Btk. gyermekkorút említ. A Gyvt. értelmező

\footnotetext{
${ }^{1}$ Btk. 160. \ (1)-(2) bek.

2 Btk. 161. S

${ }^{3}$ Btk. 164. \ (8) bek.

${ }^{4}$ Btk. 314. S (1)-(4) bek.

${ }^{5}$ Btk. 365. \ (1)-(4) bek.

${ }^{6}$ Btk. 366. (2)-(3) bek.

7 Gyvt. 5. Sa)

8 Gyvt. 5. S b)

${ }^{9}$ Gyvt. 5. S c)

${ }^{10}$ A kategória tisztán életkori skálát jelöl ki anélkül, hogy leszűkíthető lenne tényállásszerű cselekményt elkövetőkre vagy a gyermekek bármilyen jellegü minőségére.
} 
rendelkezése olyan tág halmazként határozza meg a gyermek fogalmát, amelynek részét képezi a fiatalkorúak csoportja is, tekintettel arra, hogy a Gyvt. visszautal a Ptk. szerinti kiskorú fogalmára, amely szerint kiskorú az, aki a tizennyolcadik életévét nem töltötte be. A Btk. szerint ezzel szemben az a terhelt gyermekkorú, aki a 14. életévét a bủncselekmény elkövetésekor nem töltötte be, illetőleg az, aki az emberölés, erős felindulásban elkövetett emberölés, testi sértés, rablás, kifosztás bűncselekményének elkövetésekor a tizenkettedik életévét nem töltötte be, vagy a tizenkettedik életévét betöltötte, de a tizennegyediket még nem, és ezen bủncselekmények elkövetésekor a következmények felismeréshez szükséges belátással nem rendelkezett.

A Pártfogó Felügyelői Szolgálat tevékenységéről szóló 8/2013. (VI. 29.) KIM rendelet (továbbiakban Pfr.) mind a gyermekkorú, mind a fiatalkorú kifejezést használja. A Pfr. 19/D. S (1) bekezdése alapján a gyámhatóság által a megelőző pártfogás elrendelése iránt tartott tárgyaláson az illetékes fôvárosi és megyei igazságügyi szolgálat vezetője által kijelölt pártfogó felügyelő a gyermekkorú, illetve a fiatalkorú bủnmegelőzési szempontú veszélyeztetettségének magas foka esetén részt vesz, közepes foka esetén részt vehet.

A megelőző pártfogás a járási gyámhivatalok által meghozott közigazgatási hatósági intézkedés a nyomozó hatóságok jelzésére indított esetekben, amelybe bekapcsolódik a pártfogó felügyelői szolgálat is. A közigazgatási eljárásban a Gyvt. személyi hatálya, míg a nyomozó hatóságok és a pártfogó felügyelói szolgálat szempontjából a Btk. személyi hatálya irányadó. A fent hivatkozott normaszöveg alapján megelőző pártfogás elrendelésére kizárólag tizenkettedik életévüket betöltött személyek vonatkozásában kerülhet sor, tekintettel arra, hogy az bűncselekmény vagy elzárással sújtható szabálysértés elkövetéséhez kapcsolódik. Amennyiben a jogszabály nem bűncselekményt, hanem büntetendő cselekmény kifejezést tartalmazna, elhárulna a jogértelmezési probléma, mivel tényállásszerú cselekményt a gyermekkorú személy is megvalósíthat, azzal, hogy nem büntethetô, így büntetőeljárás lefolytatására nem kerül sor.

\subsection{A büntethetőség objektív és szubjektív kategóriájának jogtörténeti változásai a Csemegi-kódextől}

A magyar szuverenitás részleges helyreállítása után, az 1861. január 23-tól március 4-ig ülésező Országbírói Értekezleten újra megfogalmazódott az igény a magyar büntetőjog kodifikálására. Az európai természetjogi kodifikációs hullámba illeszkedő magyar büntetőtörvény-tervezet $(1795)^{11}$ és az 1843. évi törvényjavaslat ${ }^{12}$ nem lépett törvényerőre, az 1848-49. évi szabadságharc bukása után pedig a neoabszolutista jogexport eredményeként 1852-ben bevezették az osztrák büntetőtörvénykönyvet ${ }^{13}$ hazánkban, amelyet mintegy kilenc évvel később az Országbírói Értekezlet határozata (ITSZ) értelmében a tradicionális magyar büntetőjog helyreállítása követett. A kor követelményeihez igazodó és tudományos szempontból is érett magyar büntető törvénykönyv kidolgozásával az Igazságügyi Minisztérium Csemegi Károlyt bízta meg. ${ }^{14}$ A

\footnotetext{
${ }^{11}$ BALOGH, Büntetőjog-történeti dogmatikai alapkérdések 6-7.

12 FINKEY, Az 1843-i büntetőjogi javaslatok 16.

${ }^{13}$ Strafgesetz über Verbrechen, Vergehen und Ubertretungen. Österreichische Nationalbibliothek Allgemeines ReichsGesetz- und Regierungsblatt für das Kaiserthum Österreich.

${ }^{14}$ FINKEY, Az 1843-i büntetőjogi javaslatok 48.
} 
tudományos felkészültségű ügyvéd és politikus a megbízásnak eleget téve elkészítette a büntető törvénykönyv tervezetét, amelyet az Országgyúlés az 1878. évi V. törvénycikként hosszas vita után elfogadott.

A Csemegi-kódex a hazai jogban mérföldkőnek volt tekinthetô a gyermek- és fiatalkorúak bűnmegelőzése szempontjából az életkori kategóriák megállapításával és az ahhoz kapcsolódó preventív intézkedések alkalmazásának lehetőségével. Megalkotására és bevezetésére az a körülmény adott okot, hogy a bủnismétlés és a visszaesés jelentős emelkedését jelentették. A háttérbe szoruló klasszikus tanok szerint kiépített büntetőjog már nem volt képes válaszokat adni a jelentkező bűnmegelőzési problémákra. Így többek között nem volt alkalmas arra, hogy a bűnözés okaival foglalkozzon, különösképpen nem az egyes bűnelkövetők motivációjával. ${ }^{15}$ Jellegzetes példája volt ennek a gyermekkorúakkal szembeni bánásmód. A gyermekkorút mint belátásra képtelen személyt kivonta a felelősségre vonhatók köréből és nem foglalkozott a reszocializációs szempontú nevelésükkel. Figyelmen kívül hagyta azt a körülményt, hogy a fiatalkorúak utánpótlását jelentő gyermekbűnözést kezelje. ${ }^{16}$ A fiatalkorúakra vonatkozó szabályok „a beszámítást kizáán vagy enybitő okok" címú fejezetben kerültek elhelyezésre. Ehhez kapcsolódóan háromféle korhatárt jelölt ki Csemegi. Az első korhatár a gyermekkor volt. A kódex gyermekkorúnak azt a személyt tekintette, „aki a büntett vagy vétség elkövetésekor életkorának tizenkettedike évét meg nem haladta”. ${ }^{17}$ A törvény értelmében a gyermekkorú személyt bűnvád alá nem vonhatták, így büntethetőségét kizárták. ${ }^{18}$

A második életkori kategóriát a tizenkettő és tizenhat év közötti büntethető fiatalkorúak képezték, amennyiben a kriminális cselekményt elkövető fiatal az elkövetés idején a tizenkettedik évét már betöltötte, de a tizenhatodikat még nem, ha a cselekménye bűnösségének felismerésére szükséges belátással bírt. Tehát a törvénykönyv a cselekményhez kapcsolódó belátási képességet rendelte a büntethetőséghez. A preventív bűnmegelőzési szemlélet az életkori kategóriához kapcsolódóan abban jelent meg, hogy a belátással nem rendelkező fiatalkorú mentesült a büntetőjogi felelősségre vonás alól, azonban a cselekmény elkövetése nem maradt értékelés nélkül. A büntetôjogi felelősségre vonás alól mentesülő fiatalkorú nem került be a büntetô igazságszolgáltatás rendszerébe, hanem - lehetőséget kapva életének korrigálására javítóintézetben történő elhelyezésére került sor. ${ }^{19} \mathrm{E}$ felfogás tehát a javítóintézetet ${ }^{20}$ nem tekintette büntetésnek, hanem olyan preventív beavatkozásnak, amely alkalmas volt a fiatalkorú életpályájának idejekorán történő kiigazítására, így nemcsak a bűncselekményt elkövetô, hanem az elhagyott, csavargó vagy a szülők kérelmére beutalt fiatalkorúak befogadását is ellátta. ${ }^{21} \mathrm{~A}$ harmadik életkori kategóriát a 20 éven aluliak alkották. A velük kapcsolatban megfogalmazott enyhítés, hogy sem halálra, sem életfogytiglani fegyházra nem itélhették őket. ${ }^{22}$

\footnotetext{
15 MEZEY, A kor kérdése 28.

16 ANGYAL, A magyar büntetőjog tankönyve 387., idézi MEZEY, A kor kérdése 29.

17 1878. évi V. tc. 83. S

18 RosTA, A fiatalkorú bűnözés 78 .

${ }^{19}$ RostA, A fiatalkorú bűnözés 79-80.

20 Az első javítóintézet létesítésére 1884-ben került sor Aszódon, ezt követte 1886-ban a kolozsvári, 1890-ben a rákospalotai (lányok részére), 1895-ben a székesfehérvári, végül 1903-ban a kassai javítóintézet felállítása.

${ }^{21}$ LŐRINCZ, A fiatalkorúak büntetés-végrehajtása 58.

22 RosTA, A fiatalkorú bűnözés 81 .
} 
Az 1908. évi XXXVI. törvénycikk a büntetőtörvények és a bûnvádi perrendtartás kiegészítésérôl és módosításáról a Csemegi-kódexhez képest két nagy előrelépést mutatott a fiatalkorúak ügyeiben. Megteremtette a felnőttekétől különböző elbánás lehetőségét és a fiatalkorúak teljes körű önálló büntetőjogi kezelését az esetükben alkalmazható intézkedések bővítésével. A fiatalkorúakra vonatkozó szabályrendszert egészítette ki a fiatalkorúak bíróságáról szóló 1913. évi VII. törvény (továbbiakban Fb.).

Az I. Büntetőnovella a gyermekkor életkori kategóriáját nem változtatta meg. Esetükben az egyéniesítés alkalmazása és a védelemre szorulás jogszabályi rögzítése adott alapot újabb intézkedések bevezetésére. ${ }^{23} \mathrm{~A}$ fiatalkor felső határát ${ }^{24}$ ugyanakkor két évvel kitolta a büntethetôség szubjektív feltételrendszerének átalakításával. A belátási képességet felváltó terminológia az értelmi és erkölcsi fejlettség lett. Ennek meglétéről előzetes eljárás keretében a bíró tájékozódott. A bírónak már nem csak a fiatalkorú értelmi fejlettségét, hanem az erkölcs szabályainak ismeretét is vizsgálnia kellett, így azt is, hogy a gyermekes vágyak, ösztönök, s mások csábításával szemben bírte némi ellenállási erővel. ${ }^{25} \mathrm{~A}$ gyakorlatban ún. külön kérdés feltevése útján döntöttek az értelmi és erkölcsi fejlettség létéről. Amennyiben a fiatalkorú ismerte a Tízparancsolatot, úgy a büntethetőséghez szükséges értelmi és erkölcsi fejlettség fokát elérte, amennyiben nem, akkor büntetőjogilag sem felelt. Kivételes esetben a büntetőjogi felelősségre vonás alól is mentesülhetett a büntethetőséghez szükséges értelmi és erkölcsi fejlettség szintjén álló fiatalkorú, amennyiben a bíróság a fiatalkorú egyéniségének, életviszonyainak és az eset összes körülményeinek megismerése után úgy döntött, hogy a bírói megdorgálás a fiatalkorú jövőbeni magaviselete és erkölcsi fejlődése szempontjából nem mutatkozik kívánatosnak. ${ }^{26}$

Az 1950-es évekre a fiatalkorúak vonatkozásában a termékeny jogalkotás volt jellemző. Az időszakot jellemző jogalkotási folyamat első állomása volt az 1950. évi II. törvény a büntetôtörvénykönyv általános részéről (továbbiakban Btá.), valamint az azt hatályba léptető 1950. évi 39. tvr. a büntetôtörvénykönyv általános részének hatályba léptetésérôl (továbbiakban Ér.). A Bta. a fiatalkorúakra vonatkozóan szűken fogalmazott, mindössze a büntethetőség alsó korhatárát állapított meg. ${ }^{27}$ Eljárásjogi szempontból megjelent a büntetőeljárás mellőzésének, megszüntetésének vagy felmentő itélet hozatalának a lehetősége, amennyiben a fiatalkorú értelmi fejletlensége okán nem ismerhette fel cselekménye társadalomra veszélyességét. ${ }^{28} \mathrm{Az}$ Ér. a fiatalkorúak vonatkozásában az I. Büntetőnovella rendelkezéseit hatályban tartotta, amennyiben az Ér. a fiatalkorúakra vonatkozóan nem tartalmazott eltérő szabályokat. Így továbbra is alkalmazhatóak voltak az I. Büntetőnovella szerinti nevelő- és óvóintézkedések és az Fb. anyagi jogi és bűnvádi eljárásjogi rendelkezései. ${ }^{29}$

\footnotetext{
${ }^{23}$ Megdorgálás és iskolai elzárás. Kriminogén szocializációs környezet a gyermek állami gyermekmenhelyre történő szállítását vonhatta maga után.

${ }^{24}$ Orvostudományi és lélektani kutatások eredményeinek és fiatalkorúak ügyeivel foglalkozó jogász konferenciák tapasztalatainak köszönhetően.

${ }^{25}$ BALÁZs, A belátási képesség 372 .

${ }^{26}$ ROSTA, A fiatalkorú bűnözés 81-86.

${ }^{27}$ A Bta. 9. \-a szerint nem büntethető az, aki nem érte el a 12. életévét.

${ }^{28}$ BALÁZs, A belátási képesség 372.

${ }^{29}$ RosTA, A fiatalkorú bűnözés 86.
} 
A termékeny jogalkotás következő eleme az 1951. évi 34. számú törvényerejủ rendelet volt a fiatalkorúakra vonatkozó büntetőjogi és büntető eljárási rendelkezésekről (továbbiakban Ftvr.). Az Ftvr. fiatalkorúak büntetőjogi felelősségre vonásával kapcsolatban valamennyi szabályt egy jogszabályban rögzítette. Így a fiatalkorúak büntetőjoga látszólagosan különvált a Btá-tól és a Büntető perrendtartástól (továbbiakban II. Bp.). ${ }^{30} \mathrm{Ez}$ azt jelentette, hogy az eljárás alapját a büntető anyagi és eljárásjogi szabályok adták, az Ftvr. csak az eltéréseket rögzítette. A fiatalkor életkori határán nem változtatott, az életkorhoz kapcsolódó szubjektív kategória kikerült a büntetőjogi felelősségre vonás feltételei közül. A büntetőeljárás mellőzésére, megszüntetésére, felmentő ítélet meghozatalára azonban lehetőséget biztosított az Ftvr. abban az esetben, ha a fiatalkorú nem ismerhette fel cselekménye társadalomra veszélyességét, továbbá ha a csekélyebb súlyú cselekményt jobbára más személy befolyása alatt követte el, és nem volt szükség vele szemben nevelő intézkedésre sem. ${ }^{31}$ A joganyag céljának meghatározásakor a bűnmegelőzési szemlélet került előtérbe. Leszögezte ugyanis, hogy a cél olyan intézkedések meghozatala, amelyek alkalmasak a fiatal megfelelő fejlődésének, illetve társadalmi beilleszkedésének előmozdítására. ${ }^{32}$

Újabb jogalkotási állomásnak számított az 1954. évi 23. számú törvényerejű rendelet a fiatalkorúakra vonatkozó büntetőjogi rendelkezések módosításáról, amely átalakította az Ftvr. életkori kategóriáit. A 12-14 évesekkel szemben bírói megrovás, próbára bocsátás, javító-nevelés és gyógypedagógiai nevelés elrendelésének volt helye. A 14-18 évesek vonatkozásában főszabály szerint büntetést kellett kiszabni, és csak a nevelés érdekében dönthetett a bíró a nevelő intézkedés elrendelése mellett. A büntetés kiszabásakor került értékelésre a fiatalkor azzal, hogy velük szemben kisebb mértékủ büntetés kiszabásának volt helye. ${ }^{33}$

Az Ftvr. alig 10 évig volt hatályban, ugyanis a Magyar Népköztársaság Büntető Törvénykönyvéről szóló 1961. évi V. törvény és az azt életbe léptető 1962. évi 10. törvényerejű rendelet hatályon kívül helyezte. A fiatalkorúak büntetőjogának elhelyezésére a büntető törvénykönyv önálló - az általános szabályokat megelőzve - VII. fejezetében került sor. A büntetőjogi felelősségre vonás feltétele továbbra is az életkor maradt és szubjektív kategóriaként megjelent az elkövetés időpontjában fennálló beszámítási képesség. A büntető törvénykönyv alapján a fiatalkorú akkor rendelkezett beszámítási képességgel, ha felismeri magatartásának társadalomra veszélyes jellegét és ennek megfelelően cselekszik. A gyermekkor felső korhatára a 14. életév lett. A fiatalkorúaknál eltörölte az Ftvr. kettős felosztását. Két évvel emelkedett a büntetôjogi felelôsségre vonás alsó korhatára, így a törvény értelmében fiatalkorúnak számított a tizennegyedik életévét betöltött, de a tizennyolcadik életévét még nem betöltött személy. ${ }^{34}$

A Büntető Törvénykönyvről szóló 1978. évi IV. törvény (továbbiakban Btk.) a szocialista jogalkotáshoz hasonlóan önálló fejezetben szabályozta a fiatalkorúakra vonatkozó külön rendelkezéseket. A törvény értelmében a felnőttek és fiatalkorúak feleltek a büntetőtörvénykönyvben meghatározott bűncselekmények elkövetéséért, amennyiben beszámítási képességgel rendelkeztek. Nem változtatott a törvény a gyermekkorúsághoz kapcsolódó életkori

\footnotetext{
${ }^{30} \mathrm{Az}$ 1951. évi III. tv.

31 Ftvr. 22. $\int$

32 RostA, A fiatalkorú bűnözés 87.

${ }^{33}$ RostA, A fiatalkorú bűnözés 87.

34 RosTA, A fiatalkorú bűnözés 88-89.
} 
kategórián. A 14 év alatti személyeket nevezte gyermekkorúnak, akiknél a büntető igazságszolgáltatás alkalmazása ki volt zárva. A fiatalkor alsó határának a 14. életévet tekintette, amelynek jogpolitikai indoka a beszámítási képesség kezdetéhez köthető. Az általános iskolai tanulmányok lezárása a 14. életévben várható. Ettől a kortól kezdődően feltételezhető, hogy a gyermek eljutott a testi és szellemi fejlettség olyan fokára, amely megalapozza a büntetőjogi felelősségre vonást. ${ }^{35}$

A gyermekkorú és fiatalkorú életkori kategóriájának megállapítása vonatkozásában változást hozott a jelenleg is hatályos új Btk. A fiatalkorúakra vonatkozó rendelkezések továbbra is a törvénykönyv Általános Részében, külön fejezetben (XI. fejezet) találhatóak.

A fiatalkor alsó határának leszállítása mögött politikai és közrendvédelmi megfontolások álltak. A jogalkotó a szektorális leszállítás mellett döntött, azaz a gyermekkor - mint büntethetôséget kizáró vagy korlátozó ok - meghatározása során tételesen felsorolta azokat a bűncselekményeket ${ }^{36}$, amelyek megvalósulása esetén fiatalkorúként értékelik az elkövetőt. Ami maga után vonta az említett vagyon elleni erőszakos és személy elleni erőszakos cselekmények elkövetőinek büntetőjogi felelősségre vonásának lehetőségét. A törvény szerint fiatalkorú az, aki a búncselekmény elkövetésekor a tizenkettedik életévét betöltötte, de a tizennyolcadikat nem. ${ }^{37}$ Gyermekkorú pedig az, aki a tizennegyedik életévét nem töltötte be, nem büntethető. ${ }^{38} \mathrm{~A}$ meghatározásból kitúnik, hogy a fiatalkor és gyermekkor életkori meghatározása átfedést mutat, amit azzal oldott fel a jogalkotó, hogy felsorolta azokat a bűncselekményeket, amelynek elkövetése esetén a tizenkettedik életévét betöltött, de tizennegyedik életévét még nem betöltött személy fiatalkorúnak minősül, és ebből adódóan fiatal kora ellenére nem áll fenn vele szemben büntethetôséget kizáró ok. A büntetőjogi felelősségre vonás szempontjából megjelent egy újabb, az életkorhoz kapcsolódó szubjektív kategória, a belátási képesség. Csak az a cselekmény elkövetésekor tizenkettedik életévét betöltött, tizennegyedik életévét még be nem töltött fiatalkorú büntethetô, aki a cselekmény elkövetésekor rendelkezett a búncselekmény következményeinek felismeréséhez szükséges belátással. Így ennek a korosztálynak a büntetőjogi felelőssége feltételes felelősség, mivel a bíróságnak minden egyes esetben vizsgálni kell, hogy az illető a bủncselekmény elkövetésekor rendelkezett-e a bűncselekmény következményeinek felismeréséhez szükséges belátással. A jogalkotó a fiatalkorúak két kategóriáját az alkalmazható jogkövetkezmények szerint osztotta fel. A tizenkettedik életévét betöltött, de tizennegyedik életévét még nem betöltött fiatalkorúval szemben nincs helye büntetés kiszabásának, csak intézkedések alkalmazhatóak. A tizennegyedik életévét betöltött, tizennyolcadik életévét még nem betöltött fiatalkorú vonatkozásában a törvénykönyv önálló fejezetében megállapított büntetések és intézkedések kiszabásának van helye. ${ }^{39}$

A fiatalkorúak életkorának szektorális leszállítása számos kritikát vont maga után. Preventív és bűnmegelőzési szempontból fontos rendelkezés, hogy velük szemben csak intézkedés alkalmazható. Azonban figyelembe véve a korosztályt érintő testi és mentális változásokat, a

\footnotetext{
35 ROSTA, A fiatalkorú bűnözés 89-90.

${ }^{36}$ Emberölés, az erős felindulásban elkövetett emberölés, a testi sértés, a terrorcselekmény, a rablás és a kifosztás.

37 Új Btk. 105.S

38 Új Btk. 16. S

${ }^{39}$ ROSTA, A fiatalkorú bűnözés 91-93.
} 
választható intézkedések tára nem volt elég széles. A kritikai észrevételek miatt 2015. január elsejétől az intézkedések sora kibővült a megelőző pártfogás lehetőségével. De nem a fiatalkorúakkal szemben büntetőeljárás keretében kiszabható intézkedések közé került, hanem a közigazgatási eljárás keretében elrendelhető hatósági intézkedések palettája bővült.

\section{A gyermekvédelem szerepe a bünmegelőzésben}

Tekintettel arra, hogy ma már tendenciaként beszélhetünk a bủnözői karrier minél fiatalabb korban való megkezdéséről, elengedhetetlen, hogy gyermekvédelmi rendszerünk preventív és konkrét bűnmegelôzési mechanizmusokat mûködtessen.

A gyermek- és fiatalkorú személyek leggyakrabban vagyon elleni bűncselekményeket követnek el, sajnálatos módon az erőszakos bủncselekmények elkövetésétől sem riadnak vissza. A vagyon elleni bűncselekmények kiemelkedően magas számából arra lehet következtetni, hogy az elkövető gyermek- és/vagy fiatalkorú személyek maguk is lehetnek veszélyeztetett élethelyzetben. Ebben a vonatkozásban a gyermekvédelem által ellátott bűnmegelőzési funkció támogató, szociális jellegének erősítése indokolt. Abban az esetben, amikor a kriminogén magatartás nem az anyagi vagy a családi veszélyeztető körülményekből fakad, a gyermekvédelem büntetô igazságszolgáltatási elemekkel való bővítése nem vitatható. Fontos lenne azonban a támogató és kontroll funkció egyensúlyának a megteremtése. Ennek egyik lehetséges módja a gyermekvédelmi szereplôk együttműködési feltételeinek protokollba foglalása és a párbeszéd lehetőségének széleskörü megteremtése. Nem lehet figyelmen kívül hagyni azt a tényt sem, hogy a bűnözés társadalmi jelenség. Ennél fogva a gyermek- és fiatalkori bűnözés kezelési módszereinek hatékonysága is komplexitást igényel.

A probléma kezelésében fontos, hogy megfelelő kezelő rendszeri válaszok együtt, egy időben hatva érvényesüljenek: egyszerre kezelve a család anyagi problémáit, a gyerek iskolai előmenetelének kérdését, támogató eszközökkel fellépve a deviáns gyermekek érdekében. ${ }^{40} \mathrm{~A}$ jog által nehezen kezelhető problémák az egyéni fejlődési eltérésekben, körülményekben és az érettség meghatározásában rejlenek. ${ }^{41}$ Éppen ezért is kavart port hazánkban a büntethetôségi korhatár ${ }^{42}$ leszállítása egyes, a korábban már említett bűncselekmények vonatkozásában.

Hatályos büntetôjogunk a fiatalkorú nevelését és védelmét tartja szem előtt, hangsúlyozva a szabadságelvonással járó intézkedés vagy büntetés ultima ratio jellegét. ${ }^{43} \mathrm{~A}$ jogalkalmazás és a szakirodalom egy része egyaránt erőteljes kritikával illeti a büntethetőségi korhatár leszállítását. A szerzők többnyire azzal érvelnek, hogy helyesebb lett volna a gyermekvédelmi intézményrendszer megelőző és válaszreakcióinak kiépítése, további kritikaként említik, hogy a büntetô igazságszolgáltatás rendszerével túl fiatalon megismerkedő személy számára az állam nem a védőóvó arcát mutatja, hanem stigmákat aggat rájuk.

\footnotetext{
${ }^{40}$ KEREZSI - KOVÁCS - PÁRKÁNYI - SZABÓ, A pártfogó felügyelet szerepe 162.

${ }^{41}$ Herzog, Gyerek elkövetők 8.

42 A belátási képesség megléte mellett, amelyhez igazságügyi elmeorvosszakértői véleményt és pszichológus szakértői véleményt is be kell szerezni. Indokolt lehet gyermekpszichiáter szakkonzulens bevonása is.

${ }^{43}$ A Btk. 105. S
} 
A magyar gyermekvédelem - a javítóintézeti nevelés és ellátás integrálásával ${ }^{44}$ - immár négy pilléren nyugszik. Az állami beavatkozás a veszélyeztetettség mértékéhez igazodik. Ennek megfelelően a pénzbeli és természetbeni ellátások nyújtása elsősorban a család életében feltárt anyagi problémákat igyekszik megoldani. A személyes gondoskodást nyújtó ellátások rendszerén belül az önkéntesség elvén múködő gyermekjóléti ellátások a családban élő gyermekek ,jólétét” hivatott szolgálni, míg a gyermekvédelmi szakellátás már kifejezetten a veszélyeztetett gyermekek számára nyújt alternatívákat. A szakellátáshoz szervesen kötődik a gyermekvédelmi gondoskodás keretében elrendelhető hatósági intézkedések köre. A hatósági intézkedések elrendelési oka alapozza meg a családból történő kiemelés lehetőségét.

Egyetértve a büntethetőségi korhatár leszállitásának elhibázottságával, azt gondolom, hogy a megelőző pártfogás éppen egy lépés a gyermekvédelmi intézményrendszer korszerűsítése felé. A motivációs különbségekből kiindulva, úgy vélem, hogy a gyermekvédelem bűnmegelőzési funkciójának egyfajta Janus arcúságot kellene hordozni azzal, hogy a szociálisan nehéz helyzetből jövő bűnelkövetôk vonatkozásában e terület védő-óvó jellegét erősítik, míg a társadalmi elvárások szempontjából deviáns magatartású gyermek- és fiatalkorúak vonatkozásában a gyermekvédelem büntető igazságszolgáltatási elemekkel történő felruházása lehet indokolt. Mindenekelőtt preferálom a helyreállító igazságszolgáltatás elemeinek gyermekvédelem rendszerébe történő telepítését, amelynek megvalósulási színtere a hatályos szabályozás alapján a megelőző pártfogás hatálya alatt állók ${ }^{45}$ számára elóírt magatartási szabályoknak ${ }^{46}$ - helyreállító konferenciamódszerek, mediáció, közösségi konfliktuskezelési technikák - a Pártfogó Felügyelői Szolgálat keretében működtetett közösségi foglalkoztatóban történő végrehajtása lehet.

\section{A bünmegelőzés fázisai}

A megelőzési-megszüntetési eszközök foka a veszélyeztetettség mértékének függvénye. A gyermek veszélyeztetettségének fogalmát a Gyvt. az értelmező rendelkezések között határozza meg. A veszélyeztetettség fogalmához hasonló, mégis a jogalkalmazói gyakorlatban attól mereven elhatárolt fogalom a gyermek hátrányos helyzete.

A szakirodalom a bűnmegelőzés első fázisába sorolja a pénzbeli- és természetbeni ellátásokat, valamint a személyes gondoskodást nyújtó gyermekjólétéi alapellátások közül a gyermekjóléti szolgáltatást. A rendőrség szerepvállalása különböző foglalkozások, programok szervezése kapcsán jelenik meg, amelynek célja kettős. Egyrészt, ha értelmes szabadidő-eltöltési lehetőséget biztosítanak a fiatalok számára, akkor a fiatalok tartózkodnak a negatív magatartástól, a bűncselekmények elkövetésétől. Másodlagos cél a rendőrség és fiatalok közötti jó kapcsolat kiépítése, hogy a rendőrség képes legyen pozitív társadalmi értékeket közvetíteni, és segítséget tudjon nyújtani, hogy a fiatalok pozitív célkitűzésű társadalmi csoportokba integrálódjanak.

A szolgáltatást nyújtó gyermekjóléti szolgálat az információáramlás központja (járásszékhely településen a Család- és Gyermekjóléti Központ), hozzá futnak be a jelzések az egészségügy, a közoktatás, a civil szféra és az állampolgárok, valamint szerencsés esetben a

\footnotetext{
${ }^{44}$ Gyvt. 66/M. S

45 Gyvt 68/D. $\int(7)$ bekezdés

${ }^{46}$ Pfr. 19/K. $\int(2)$ bekezdés b) pont
} 
rendőrség részéről. A szolgálat közvetít a gyámhatóság és a gyermek krízisállapotát észlelő szervek között.

Az elsődleges és másodlagos prevenció körében olyan társadalmi feltételeket és infrastrukturális hátteret kell kialakítani, amely képes biztosítani a fiatalkorúak anyagi és szellemi jólétét. Meg kell teremteni a szocializációs helyszínek múködési feltételeit is, mert leginkább ebben az életszakaszban fogékonyak a fiatalok a viselkedésminták eltanulására. A megfelelő szocializáció és a bűnmegelőzési szempontokat is figyelembe vevő szociálpolitika a minimumra szoríthatja a bűnelkövetést és a fiatalkorúak igazságszolgáltatási rendszerének beavatkozását, így csökkentve az ártalmat, amit az intervenció okozhat. ${ }^{47}$

A másodlagos megelőzés a speciális gyermekvédelem szférájába tartozik, a cél immár a veszélyhelyzet megszüntetése. ${ }^{48} \mathrm{~A}$ gyermekvédelmi rendszer a védelembe vétel és részben a megelőző pártfogás hatósági intézkedés révén kapcsolódik a másodlagos bűnmegelőzéshez. Ebben a fázisban már nem a veszélyeztetettség megelőzésén, hanem a megszüntetésén van a hangsúly. A cél az, hogy az a gyermek- vagy fiatalkorú személy, aki már védelembe vétel hatálya alatt áll vagy a megelőző pártfogás elrendelésével védelembe vételére kerül sor, ne kövessen el a jövőben további kriminális cselekményeket. Ezt hivatott szolgálni a magatartási szabályok előirása-betartatása, valamint a gondozási-nevelési terv.

Ebben a fázisban kellene helyet kapnia egy intézményes konfliktus-kezelő szolgáltatásnak. A gyermek- és fiatalkorúak által elkövetett szabálysértések és bűncselekmények jelentős részét azok a cselekmények képezik, amelynek alapját valamely konfliktushelyzet generálja. A kommunikáció nem megfelelő ismerete miatt olykor banális félreértésekből adódnak az ún. „balesetek”. A védelembe vétel és megelőző pártfogás körében előírt magatartási szabályok között eseti jelleggel szerepel az iskola-pszichológusi vizsgálaton, illetve konfliktuskezelést-segítő szolgáltatáson való részvétel. ${ }^{49}$ Meggyőződésem, hogy a bűnmegelőzés hatékonyságát szolgálná, ha az oktatási rendszerbe integráltan, az általános iskola felső tagozatától lehetőség lenne - akár konkrét konfliktus kapcsán, akár eseti jelleggel - igénybe venni konfliktuskezelő-kommunikációt fejlesztő szolgáltatást. ${ }^{50}$ Kétségtelen, hogy a sport, mint feszültség levezető és tanulási képességeket generáló tevékenység és a sportközösségek, mint szocializációs csoportok hatása a másodlagos bűnmegelőzés körében kiemelkedő. ${ }^{51}$

A harmadlagos megelőzés a már megtörtént búncselekményekre való intézményes reakciókat tartalmazza olyan intézkedésekkel és beavatkozásokkal, amelyek az ismételt búnelkövetés és áldozattá válás elkerülését célozzák. ${ }^{52}$

A büntető anyagi- és eljárásjog körében számos jogintézmény (diverzió, alternatív szankciók, gyermek meghallgatásának intézménye, pártfogó felügyelet, javító intézeti nevelés stb.)

\footnotetext{
${ }^{47}$ KOVÁCS, Fiatalkorú bűnelkövetők 3.

${ }^{48}$ SÁRIK, A gyermek- és fiatalkori bűnözés 6.

${ }^{49}$ Baranya megyei információk alapján a konfliktuskezelést-segítő szolgáltatáson való kötelező részvétel nem szerepel az előírt magatartási szabályok között.

${ }^{50}$ Lásd a Nemzeti Bűnmegelőzési Stratégia 1. számú mellékletének a „Konfliktusok és az erőszak megelőzése, kezelése” 8.2.3. pontját és az ahhoz füzött intézkedések köréből a módszertan készítését az iskolai erőszak hatékony megelőzése érdekében, valamint az iskolai mediátor képzése.

${ }^{51}$ Lásd a Nemzeti Bűnmegelőzési Stratégia 1. számú mellékletének a „Hasznos szabadidő- eltöltés” 8.2.2 pontját és az ehhez füzött intézkedés a testnevelő tanárok és edzők bűnmegelőzési továbbképzésének bevezetése.

52 GÖNCZÖL, A bűnözés társadalmi reprodukciója 320.
} 
hivatott a harmadlagos megelőzés érdekeit, hatékonyságát szolgálni. Véleményem szerint ezt egészíti ki a gyermekvédelmi rendszerben megjelent megelőző pártfogás jogintézménye, tekintettel arra, hogy az elrendelés jogalapja a megelőző pártfogó által elkészített kockázatértékelés bűnmegelőzés szempontjából releváns foka. Amennyiben a gyermek- vagy fiatalkorú vonatkozásában elvégzett kockázatértékelés magas, az illetékes gyámhatóságnak kötelezően el kell rendelnie az intézkedést. Amennyiben a kockázatértékelés közepes fokú, a gyámhatóság mérlegelési körébe tartozik a megelőző pártfogás elrendelése. Tovább erősíti a megelőző jelleget, hogy a gyámhatóság által meghozott, megelőző pártfogás elrendelésére irányuló határozatban alapul veszik a megelőző pártfogó véleményében foglalt magatartási szabályokat, és a magatartási szabályok ellenőrzésében a pártfogó felügyelői szolgálat is részt vesz. Amennyiben nemcsak tényállásszerūen kerül sor bûncselekmény megvalósítására, hanem a fiatalkorú életkora és beszámítási képessége alapján bűncselekmény elkövetője lehet, a megelőző pártfogás gyermekvédelmi hatósági intézkedéssel párhuzamosan büntetőeljárás is folyik. Ez további kontrollfunkciót is betölthet a bűnmegelőzés körében, ugyanakkor a prevenció elvével ellentétben állhat.

\section{A Fiatalkorúak Felügyelő Hatósága által elrendelhető patronázstól a modern megelőző pártfogásig}

A gyermekvédelmi rendszerben elhelyezésre került fiatalkorú elkövetőkkel foglalkozó pártfogói szolgálatot 1970-ben állították fel. ${ }^{53}$ Ezt megelőzően ilyen integrált, bűnmegelőzési célzatú jogintézménnyel a Fiatalkorúak Felügyelő Hatósága ${ }^{54}$ (továbbiakban: Hatóság ${ }^{55}$ ) által elrendelhető intézkedések kapcsán találkozunk. A Hatóság által elrendelt intézkedések azonban történetileg nem tekinthetőek a megelőző pártfogás jogelődjének. Tartalmukban ${ }^{56}$, eszköztárukban (kiemelve a kriminálpolitikai célzatú patronázs fogalmát) túlmutatnak a napjaink hatósági intézkedésén, végrehajtási lehetőségein - amely a bizalom megnyerésében és a meggyőzés útjának kialakításában nyilvánult meg ${ }^{57}$ - meglehetôsen korlátozottak voltak. A fiatalkorúak pártfogó felügyelete a fiatalkorúak ügyeiben eljáró bíróságok tevékenységéhez kapcsolódtak elsősorban. ${ }^{58}$

Az önálló fiatalkorúak bíróságának felállítása ${ }^{59}$ a fiatalkorúakkal szembeni bánásmód megváltozását jelezte. A Fiatalkorúak Hatósága által rendezett, 1942 december 10-én tartott előadáson Alföldy Dezső́ leszögezte, hogy „a fiatalkorúak birájának feladata nemcsak az, hogy azzal a fiatalkorúval szemben, aki már büncselekményt elkövetett, annak javitása érdekében a törvényben meghatározott intézkedéseket alkalmazza, hanem a fiatalkorúak biróságának bivatása az is, hogy az erkölcsi veszedelemnek kitett és züllésnek indult, de büncselekményt még el nem követett gyermekekel és fiatalkorúval szemben annak. megmentése érdekében a célravezetönek vélt intéžkedést megtegye, nehogy a bünözés útjára lépjen." ${ }^{60}$ A gyermek-

\footnotetext{
53 VÓKÓ, Elmélkedés a pártfogó felügyeletről 49-69.

${ }^{54}$ Az erkölcsi züllés veszélyének kitett gyermekek és a bűnelkövető gyermekek és fiatalkorúak ügyeit első fokon intéző hatóságok segítő és felügyeletéti szerve. Lásd FINKEY, Patronázs-munka 7.

55 Az 1908. évi XXXVI. törvénycikk felhatalmazása alapján állították fel és dolgozták ki szervezetrendszerét

56 ALFÖLDY, Bíróság és patronázs 202.

57 ALFÖLDY, Bíróság és patronázs 206.

58 ALFÖLDY, Bíróság és patronázs 201.

${ }^{59}$ A fiatalkorúak bíróságáról szóló 1913. évi VII. törvény adott jogszabályi alapot a fiatalkorúak bíróságának felállítására.

${ }^{60}$ ALFÖLDY, Bíróság és patronázs 201.
} 
és fiatalkorúak megmentésének jogszabályi felhatalmazáson alapuló korabeli lehetőségének számított a patronázs munka, amely Finkey Ferenc - a Fiatalkorúak Budapesti Felügyelő Hatóságának egykori elnöke - szerint akkor tudja betölteni a megmentő szerepet, ha a patronázs egyaránt állami és társadalmi feladat is. ${ }^{61}$ Ezt támasztja alá Angyal Pál véleménye is, aki szerint „a patronázs ügy fejlódése séletképessége attól függ, mily mértékben vesz abban részt a nagy társadalom", ezért a kormány támogatása mellett a Patronage Egyesületek Országos Szövetségének kell az alapítási munkálatokat elvégeznie és irányítania. ${ }^{62}$

A Bn. a pártfogó felügyelet két esetét ismerte. Az általános - a fent hivatkozott erkölcsi veszedelemnek kitett és züllés útjára lépő gyermek- és fiatalkorúak vonatkozásában - és egy speciális - a javító intézetből való kísérleti kihelyezés és a feltételes szabadon bocsátáshoz kapcsolódó ${ }^{63}$ - segítő, ellenőrző tevékenységet különböztetett meg. A speciális ellenőrzés tulajdonképpen az utógondozás területét érintette. A Bn. ezen rendelkezésének végrehajtására alkotott igazságügyminiszteri rendelet ${ }^{64}$ kétféle pártfogót ismert: a társadalmi pártfogókat, akiket a gyermekvédő egyesületek tagjai közül toboroztak és hivatásos pártfogókat. ${ }^{65}$ Fiatalkorúak felügyelő hatóságát a Bn. 31. \-a alapján minden javító intézet és fiatalkorúak befogadására szolgáló fogház mellett fel kellett állítani. ${ }^{66}$ A reformtörekvések azt követelték, hogy a szabadságvesztés időtartama nyújtson lehetőséget a fiatalkorú átalakítására, tartalma pedig - főképpen a munkára, életmódra szoktatás és a szakmai felkészítés hangsúlyozásával - növelje a társadalomba beilleszkedés jövőbeli esélyeit. ${ }^{67}$ A pártfogó felügyelői tevékenység ily módon történő megkülönböztetése különböző típusú feladatellátást igényelt. Tágan vett értelemben ugyan, de kapcsolódik a bűnmegelőzés területéhez, amikor a gyermek- illetve fiatalkorú személy a szülői-családi környezetben bekövetkezett változás miatt van veszélynek kitéve. A felügyelő hatóság állományában dolgozó pártfogó felügyelő feladata gyakran a házassági perben észlelt veszélyhelyzet feltárásához is kapcsolódott. A bontóperben eljáró bíró megbízhatta a pártfogó felügyelőt, hogy tájékozódjon a házasfelek közötti viszály okairól, a vétkesség kérdéséről, a gyermekkel szemben fennálló elhanyagolás körülményeirôl. Ennek során a pártfogó felügyelő környezettanulmányt vett fel. A környezettanulmányt a perbíróság felhasználhatta, egyebekben a bírónak nem volt eszköze a veszélyhelyzet észlelése esetén. A környezettanulmány elkészítésén túl a pártfogó felügyelő segíthetett az anyagilag bajba jutott szülőnek munkát találni, biztosítva ezzel a család megélhetését, továbbá gondoskodott a gyermek megfelelő közoktatási intézményben történő elhelyezéséről vagy ha már nagyobb volt, segítette a munkába állásban. Feladatköre kiterjedt arra is, hogy a gyermektartás fizetésére kötelezett felet a saját otthonában felkeresse és tapintattal ugyan, de rábírja a gyermekéről történő anyagi gondoskodásra. ${ }^{68}$ Szankcióként a bíróság a korábban már említett intézkedések bármelyikét alkalmazhatta, valamint a büntetőeljárás menetére nézve további óvó,

\footnotetext{
${ }^{61}$ FINKEY, Patronázs-munka 6.

62 ANGYAL, A patronage 488-489.

${ }^{63}$ 56.000/1913. I. M. E. sz., az Fb.-hez kapcsolódó végrehajtási rendelet alapján

${ }^{64} 27.400 / 1909$. I. M. sz. r.

${ }^{65}$ A patronázs tevékenység alanyainak kérdése a korabeli bűnmegelőzéssel foglalkozó szakemberek körében vitatott volt, amely vita az 1907. évi pécsi országos patronázs kongresszuson élesedett ki.

${ }^{66}$ DÁvid, A hazai pártfogó felügyelet 62.

${ }^{67}$ LÖRINCZ, A fiatalkorúak 60.

${ }^{68}$ ALFÖLDY, Bíróság és patronázs 203-207.
} 
nevelő célzatú egyszerűsítést vezettek be. Ilyen volt például a bíró számára biztosított lehetôség, hogy akár tárgyalás megtartása nélkül is kiválaszthatta a legmegfelelőbb javító-nevelő intézkedést vagy a tárgyalás megtartása esetén dönthetett a nyilvánosság csökkentéséről vagy annak teljes kizárását rendelhette el. ${ }^{69}$

Az első világháború veszteségei a bűnözésre is kihatottak, így csökkent az igazságügyi értelemben vett pártfogásra szorulók száma. A patronázs szervezetek közreműködtek a háború következtében megnövekedett szociális feladatok ellátásában, a javító és nevelőintézetek növendékei javítási, ápolási feladatokat láttak el vagy az elmaradt mezei munkáknál segítettek. 1933ban még megalakult a Patronázs Szövetségek Magyar Egyesülete, azonban lendületét a II. világháború megtörte. $^{70}$

A szocialista korszak célkitűzései között szerepelt az ún. teljes körű foglalkoztatottság, amelynek előtérbe helyezésével az utógondozás gondolata háttérbe szorult a szabadulást követő beszélgetések formájával és az élelmiszer- és ruhatámogatással. Az 1951. évi 34. tvr. a helyi tanácsok végrehajtó bizottságainak kezébe adta a fiatalkorúak ellenőrzésének és gondozásának feladatát. A patronázs eszme feléledésének tekinthető, hogy a Magyar Népköztársaság Büntető Törvénykönyve szabályozta a pártfogó felügyeletet és bővítette annak alkalmazási lehetőségeit. A fiatalkorú elkövetőkkel foglalkozó pártfogó szolgálat felállítására 1970-ben került sor a 131/1970. (M.K. 15.) MM utasítással a gyermekvédelem rendszerében azzal a céllal, hogy a gyámhivatali védő-óvó intézkedések, valamint az utógondozás hatékonyságát növeljék. ${ }^{71}$ A gyámhatósági eljárásról szóló 1/1974. (VI. 27.) OM rendelet 73. \-a szerint a gyámhatóság védő- és óvóintézkedést rendelhetett el a büntetőeljárás keretein kívül abban az esetben, ha a kiskorú erkölcsi fejlődése, nevelése, gondozása nem volt biztosított, valamint kötelező magatartási szabályai felállítása során a szülőt is felszólíthatta. Az eljárás lefolytatása során a gyámhatóság a kiskorú részére pártfogót rendelhetett. A pártfogó feladata a felügyeletére bízott kiskorú magatartásának figyelemmel kísérése volt, szükség esetén a szülőt is segíthette nevelési feladataiban. Ezt követően az oktatási miniszter által kiadott 6/1980. (VI. 24.) OM rendelet szabályozta a gyámhivatalok és a hivatásos pártfogók feladatait.

A Gyvt. 1997-ben a pártfogók helyzetét generálisan átalakította azzal, hogy a hivatásos pártfogói csoportot a másodfokú gyámhivatalként múködő, akkori nevén megyei közigazgatási hivatal gyermekvédelmi és gyámügyi igazgatási szervéhez telepítette. 2003. július 1. napjától ${ }^{72}$ a fiatalkorú és felnőtt terheltekkel foglalkozó pártfogó felügyelőket egy szervezetbe integrálták Pártfogó Felügyelői Szolgálat elnevezés alatt. A bűnismétlés kockázatának mérséklésén dolgozó szociális munkás és pártfogó segítséget nyújt a fiatalok életvezetési gondjainak megoldásában és a konfliktuskezelésben egyaránt. Feladatkörüket a korábban már hivatkozott PFSZ. szabályozza.

Az ismertetett hatósági megoldások azonban nem feleltek meg sem a kormányzat, sem a társadalom által megfogalmazott kriminálpolitikai elvárásoknak. Tendenciaként volt kimutatható az elkövetői kör egyre alacsonyabb életkora. Az alacsony életkorhoz sok esetben társult erôszakos magatartás. A büntethetőségi korhatár leszállítása széleskörű társadalmi és szakmai vitát generált. A jogalkotó által, a társadalmi igények felmérését követően megfogalmazott cél egy olyan

\footnotetext{
${ }^{69}$ LŐRINCZ, A fiatalkorúak 65-66.

${ }^{70}$ FINKEY, A patronage a háború alatt és a háború után 387. Idézi DÁvID, A hazai pártfogó felügyelet 66-67.

${ }^{71}$ DÁvID, A hazai pártfogó felügyelet 68-69.

${ }^{72}$ A pártfogókra vonatkozó egyes törvények módosításáról szóló 2003. évi XIV. törvény alapján
} 
jogintézmény megalkotása volt, amely alkalmas a gyermek- és fiatalkorúak bűnmegelőzésére, és egyúttal a terheltek társadalomba történő visszailleszkedésére. A büntetőjog fiatalkorúak vonatkozásában ismert olyan eszközöket, amelyek a megfogalmazott jogpolitikai cél kiváltására alkalmasak lehetnek, ugyanakkor a gyermekek vonatkozásában a megelőző pártfogás bevezetését megelőzően kizárólag a védelembe vételi eljárás elrendelése során kerülhetett „fokozottabb figyelem- és ellenőrzés" alá az a gyermek, aki hajlandóságot mutatott a kriminalizálódásra, akár személyében felmerült körülmények miatt, akár a családon belüli veszélyeztető körülményeknek köszönhetően.

A 1430/2011. (XII. 13.) Korm. határozat a Nemzeti Társadalmi Felzárkózási Stratégiáról, valamint végrehajtásának a 2012-2014. évekre szóló kormányzati intézkedési tervérôl, és az egyes törvényeknek a gyermekek védelme érdekében történő módosításáról szóló T/13091. számú törvényjavaslat indokolás a gyermek-és fiatalkorú elítéltek visszaesésének megakadályozása és a társadalomba való hatékonyabb visszailleszkedése érdekében fogalmazta meg a jogpolitikai igényt egy új jogintézmény bevezetésére a gyermekvédelem rendszerében.

Az intézkedés rendszertani elhelyezése kezdetektől fogva vitatott volt. Ez a vita elsősorban a megfogalmazott jogpolitikai célkitűzésből eredt. A rendszertani elhelyezést ellenzők véleménye szerint bűnmegelőzés és bűnismétlés fogalma és eszközrendszere büntetôpolitikai megközelítést és fellépést igényel, így az új jogintézménynek a célja alapján a büntetô anyagi- vagy eljárásjogi eszközök sorát kellene bővítenie. A megalkotott mechanizmus kriminológiai tárgyú kutatások szerint eredményét tekintve a kijelölt feladat megvalósítása az igazságszolgáltatási reakció gyermekvédelembe integrálásával. ${ }^{73}$

További vitatott kérdés az intézkedés megelőző jellege illetve elnevezése. Az elnevezés büntető anyagi- és eljárásjogi értelemben utal arra, hogy az intézkedés megelőzi vagy kiegészíti a büntetőeljárást. Amennyiben gyermek a gyermekvédelmi törvény tényállási elemeit megvalósító személy, közigazgatási hatósági eljárás indul és a megelőző pártfogó által elkészített kockázatértékelés fokától függően védelembe vételi eljárás keretében a gyámhatóság elrendelheti a tárgyalt intézkedést. Ha a terhelt életkora vagy beszámítási képessége alapján bűncselekményt vagy elzárással is sújtható szabálysértést követ el, nemcsak közigazgatási hatósági eljárás, hanem büntetőeljárás is folyik vele szemben. Ebben az esetben a megelőző elnevezés használata értelmezhetetlen. Hiszen a büntetőeljárást nem megelőzi a gyermekvédelmi hatósági intézkedés, hanem párhuzamosan zajlik, ad abszurdum tovább is tarthat, amennyiben a büntetőeljárás ügyészi megrovással, feltételes ügyészi felfüggesztéssel ${ }^{74}$ vagy közvetítői eljárással lezárul a bírósági szakra terelés előtt.

Krimininológiai vonatkozású értelmezése egy lehetőség a bűnözői karrier útjára lépés megakadályozására, illetve a kriminalizálódott személyek társadalmilag helyes irányba terelésére. Az intézkedés kriminológiai szempontból a harmadlagos prevenció területén történő beavatkozás a

\footnotetext{
${ }^{73}$ KEREZSI - KOVÁCS - PÁRKÁNYI - SZABÓ, A pártfogó felügyelet szerepe 154.

${ }^{74} \mathrm{Az}$ új Be. a korábbi vádelhalasztásnak megfelelő jogintézményként szabályozza a feltételes ügyészi felfüggesztést. Ez az intézkedés azonban nemcsak elnevezésében új, hanem jóval tágabb körben is alkalmazható (elég csak arra utalni, hogy fiatalkorú esetén akár 8 évi szabadságvesztéssel fenyegetett bűncselekmények esetén is sor kerülhet feltételes ügyészi felfüggesztésre, míg a vádemelés elhalasztásánál 5 év volt a felső határ).
} 
bűnismétlés kockázatának kitett gyermek és fiatalkorú érdekében, amelyhez az eszközrendszert az elsődleges és másodlagos bủnmegelőzési színtérrel bíró gyermekvédelemből meríti a jogalkotó. ${ }^{75}$ A gyermek segítésével foglalkozó szakmák szempontjából a megelőzés kérdése nem elsősorban a bűnmegelőzés, hanem a veszélyeztetettség fogalmához kapcsolódik. A két terület természetesen számos átfedést mutat és nyilvánvalóan okozati összefüggések is kimutathatóak.

\section{Következtetések}

Alföldy Dęső 20. század közepén megfogalmazott gondolatai mai is helytállóak: „A gyermekvédelem szempontjából különös jelentösége van azoknak az állami és társadalmi intézkedéseknek, amelyek a bünözó, vagy a züllésnek induló, vagy még csak erkölcsileg veszélyeztetett gyermekek és fiatalkorúak megmentésére irányulnak."76 A megelőző pártfogás fejlődését - különös tekintettel Baranya megyére - hatályba lépésétől kezdve nyomon követtem. 2015 nyarán, a jogintézmény bevezetését követő fél év elteltével, írásban kerestem meg a Baranya megyei, megelőző pártfogással kapcsolatba kerülő jogalkalmazó szerveket. Megkeresésem a jogintézmény elrendelésére, alkalmazásának gyakoriságára és hatékonyságára vonatkozó kérdőív kitöltésére irányult. Egy évvel később ismételten felkerestem az érintett szerveket a hatékonyság vonatkozásában leszűrhető következtetések megállapítása érdekében. 2018 nyarán valamennyi, a Baranya Megyei Kormányhivatal Hatósági Főosztályának Igazságügyi Osztályán fellelhető, az elrendelt megelőző pártfogásban történő közreműködésük kapcsán keletkezett ügyiratot átvizsgáltam. Az empirikus módszer alkalmazása mellett a téma értelmezéséhez szükséges történeti és leíró jellegû megközelítést alkalmaztam.

Elképzelésem szerint új utat mutathatna a megelőző pártfogás hatékonysága terén a családi csoport konferencia vagy közösségi csoportkonferencia bevezetése. ${ }^{77}$ A hazai szakirodalom elsősorban a büntető igazságszolgáltatás rendszerében látja létjogosultságát a modellnek. Ugyanakkor láthatjuk, hogy a jelenlegi magyarországi gyermekvédelmi és igazságügyi rendszer tehetetlen a tizennégy (egyes bűncselekmények esetén tizenkét) év alatti, bűncselekményt vagy tényállásszerú cselekményt elkövető gyermekekkel szemben. A családi csoportkonferencia módszere megköveteli az interdiszciplináris és interszektorális megközelítést, sikeres alkalmazásának így elsődleges feltétele a segítő szakmák és hatóságok közötti hatékony együttmúködés. ${ }^{78}$ A helyreállító igazságszolgáltatás olyan megközelítést jelent, amelyben a sértett, az elkövető és a közösség közösen keres megoldást a bűncselekmény által okozott konfliktus következményeire. Célja az okozott kár helyreállításának szorgalmazása, a felek közötti helyzet rendezése, a kollektív biztonságérzet erősítése. Megbélyegző hatása elenyésző, pedagógiai értéke magas és kevésbé büntető jellegű. ${ }^{79}$

\footnotetext{
${ }^{75}$ KEREZSI - KOVÁCS - PÁRKÁNYI - SZABÓ, A pártfogó felügyelet szerepe 154.

76 ALFÖLDY, Bíróság és patronázs 200.

77 A helyreállító igazságszolgáltatás körében alkalmazható modell. Gyökerei Új-Zélandról származnak, 1989-ben a gyermekek, fiatalkorúak és családjaik védelméről szóló törvény forradalmasította a fiatalkorúak igazságszolgáltatási eljárását Új-Zélandon. Magyarországon a konferenciamodell alkalmazását a Közösségi Szolgáltatások Alapítványa és a Család, Gyermek, Ifjúság Egyesület kezdte meg 2006-ban.

${ }^{78}$ FELLEGI, Út a megbékéléshez 191.

${ }^{79}$ Európai Gazdasági és Szociális Bizottság 2006/C 110/13 számú véleményének 4.3-4-4 pontjai
} 


\section{Felhasznált források és irodalom}

1878. évi V. tc.a magyar büntetőtörvénykönyv a bűntettekről és büntetésekről = Csemegi-kódex 1908. évi XXXVI. tc. a büntetőtörvények és a bűnvádi perrendtartás kiegészítéséről és módosításáról

1913. évi VII. tc. a fiatalkorúak bíróságáról szóló = Fb.

1950. évi II. tv. a büntetőtörvénykönyv általános részéről = Btá.

1950. évi 39. tvr. a büntetőtörvénykönyv általános részének hatályba léptetéséről = Ér.

1951. évi 34. tvr. a fiatalkorúakra vonatkozó büntetőjogi és büntető eljárási rendelkezésekről = Ftvr.

1951. évi III. tv. a büntető perrendtartástól = II. Bp.

1954. évi 23. tvr. a fiatalkorúakra vonatkozó büntetőjogi rendelkezések módosításáról

1961. évi V. tv. a Magyar Népköztársaság Büntető Törvénykönyvéről

1962. évi 10. tvr. a Büntető Törvénykönyv hatálybaléptetéséről, végrehajtásáról és egyes szabálysértésekről

1/1974. (VI.27.) OM rend. a gyámhatósági eljárásról szóló

1978. évi IV. tv. a Büntető Törvénykönyvről = régi Btk.

6/1980. (VI. 24.) OM rend. a fiatalkorúak pártfogó felügyeletéről, a javítóintézeti nevelésrôl és egyes eljárási rendelkezésekről

1996. évi I. tv. a rádiózásról és televíziózásról szóló

1997. évi XXXI. tv. a gyermekek védelméről és a gyámügyi igazgatásról = Gyvt.

2003. évi XIV. tv. a pártfogókra vonatkozó egyes törvények módosításáról

1430/2011. (XII.13.) Korm. határozat a Nemzeti Társadalmi Felzárkózási Stratégiáról, valamint végrehajtásának a 2012-2014. évekre szóló kormányzati intézkedési tervéről

2013. évi V. tv. a Polgári Törvénykönyvről = Ptk.

2012. évi C. tv. a Büntető Törvénykönyvről = új Btk.

8/2013. (VI. 29.) KIM rendelet a Pártfogó Felügyelői Szolgálat tevékenységéről = Pfr.

2013. évi CCXLV. tv. az egyes törvényeknek a gyermekek érdekében történő módosításáról s

1744/2013 (X. 17.) Korm. határozat a Nemzeti Bűnmegelőzési Stratégiáról (2013-2023)

2017. évi XC. tv. a büntetőeljárásról

ALFÖLDY Dezső: Bíróság és patronázs. Magyar Jogi Szemle 1943/7. sz. 200-209.

ANGYAL Pál: A patronage. Jogállam 1909/7. sz. 481-490.

BALÁZs Beáta: A belátási képesség büntetőjogi fogalmának történeti és elvi alapjairól. Magyar Jog 2018/6. sz. 370-377.

BALOGH Elemér: Büntetőjog - történeti dogmatikai alapkérdések. Rendszertani kísérletek a korai magyar büntetőjogi kodifikációban. Jogtörténeti Szemle 2016/3 sz. 3-12.

CSEMÁNÉ VÁRADI Erika: A gyermek és fiatalkori bűnözés - tendenciák, elméletek, okok. Kriminológiai Közlemények, 2001, 55-91.

DÁvID Lilla: A hazai pártfogó felügyelet intézkedésének szerepe a fiatalkorúak bűnelkövetésének megelőzésében. Msc. 2013.

DÁvID Lilla: Megelőző pártfogás vagy védelembe vétel? Állam és Jogtudomány 2013/3-4. sz. 4154 
FELLEGI Borbála: Út a megbékéléshez. Budapest 2009

FINKEY Ferenc: A patronage a háború alatt és a háború után. Bűnügyi Szemle 1915/9. sz. 385397.

FINKEY Ferenc: Az 1843-i büntetőjogi javaslatok száz év távlatából. Budapest 1943

FINKEY Ferenc: Patronázs-munka és a Fiatalkorúak Felügyelő Hatósága. Magyar Jogi Szemle 1943/1. sz. 1-16.

GÖNCZÖL Katalin: A bűnözés társadalmi reprodukciója. Kriminológia-Szakkriminológia. Budapest 2006

Herczog Mária: Gyerek elkövetők, felnőtt bűnök. Családi jog 2008/3. sz. 4-10.

Herczog Mária: Családi Csoportkonferencia: A konfliktuskezelés egy konstruktív módszere. In: Szeibert Orsolya (szerk.): Család, gyermek, vagyon. A joggyakorlat kihívásai. Családjogi tanulmánykötet. Budapest 2012, 409-425.

HORNYÁK Szabolcs: A gyermekkorúak bűnözése és megelőzésének lehetőségei. Határőrség és bűnmegelôzés 2003/12. sz. 41-48.

KEREZSI Klára - KOVÁCS Krisztina - PÁRKÁNYI Eszter - SZABÓ Judit: A pártfogó felügyelet szerepe a bűnmegelőzésben, különös tekintettel a jogintézmény tervezett változásaira. In: VÓKÓ György (szerk.): Kriminológiai Tanulmányok 52. Budapest 2015, 148-191.

KIRÁLY Réka Zsuzsa: A gyermekbűnözés kriminológiai ismérvei. Belügyi Szemle 2000/12. sz. 4148.

KOVÁCS Krisztina: Fiatalkorú bűnelkövetők reszocializációs nevelése. Speciálpreventív beavatkozások a szabadságvesztés alatt és azt követően. De iurisprudentia et iuro publico 2013/2. http:/ / mjat.hu/aktualis/449-megjelent-a-de-iurisprudentia-et-iure-publico-jog-es-

politikatudomanyi-folyoirat-2013-2-szama

LŐRINCZ József: A fiatalkorúak büntetés-végrehajtása a XX. század első felében. Börtönügyi Szemle 2002/2. sz. 57-66.

MEZEY Barna: A kor kérdése a magyar büntetőjog történetében. A fiatalkorú bűnelkövetők történetéhez. Rendészeti Szemle 2008/7-8. sz. 21-30.

PÁlVÖLGYI Ákos: A megelőző pártfogás, mint a bűnmegelőzés egyik lehetséges eszköze. Büntetőjogi Szemle 2012/2. sz. 29-34.

RosTA Andrea: A fiatalkorú búnözés kriminológiája és szociológiája. Budapest 2014

SÁRIK Eszter: A gyermek- és fiatalkori bűnözés megelőzési lehetőségei. Család, Gyermek, Ifjúság 2000/2. sz. 4-13.

VAVRÓ István: Fiatalkorú elítéltek 2000. Belügyi Szemle 2002/1. sz. 52-58.

VÓKÓ György: Elmélkedés a pártfogó felügyeletről. Börtönügyi Szemle 2003/1. sz. 49-69. 